\title{
Assessment of Functional Status and Quality of Life of Elderly Patients Undergoing Radiotherapy and Radiotherapy Combined with Chemotherapy - A Cross-Sectional Study
}

This article was published in the following Dove Press journal: Clinical Interventions in Aging

\author{
Marta Muszalik (D) \\ Iwona Repka ${ }^{2}$ \\ Grażyna Puto ${ }^{2}$ \\ Justyna Kowal-Skałka² \\ Kornelia Kędziora- \\ Kornatowska' \\ 'Department of Geriatrics, Nicolaus \\ Copernicus University in Torun, \\ Collegium Medicum in Bydgoszcz, \\ Bydgoszcz, 85-094, Poland; ${ }^{2}$ Department \\ of Clinical Nursing, Institute of Nursing \\ and Midwifery, Faculty of Health Sciences, \\ Jagiellonian University Medical College \\ Cracow, Kraków 31-50I, Poland
}

Background: Aging is associated with various diseases, a plethora of which are oncological. Selected treatment methods influence the performance status and the adaptability to changing circumstances.

Objective: The aim of the study was to assess the functional status, quality of life, and adaptation to disease of elderly patients who underwent only radiotherapy or chemotherapy combined with radiotherapy.

Patients and Methods: The cross-sectional study was conducted in a sample of 76 patients diagnosed with cancer, over 60 years of age (mean 69.3/SD 6.8) who were hospitalized in the Radiotherapy Department at the Ludwik Rydygier Hospital in Krakow. Standardized research tools were: Functional Assessment of Chronic Illness Therapy (FACIT-F), Mental Adjustment to Cancer Scale (Mini-MAC), Lawton Instrumental Activity of Daily Living (IADL), Yesavage Geriatric Depression Scale (GDS), an assessment scale of the post radiation reaction devised by Eastern Cooperative Oncology Group (ECOG).

Results: Most $(\mathrm{n}=37)$ patients were treated with a combination of radiotherapy and chemotherapy $(48.6 \%)$, whereas 21 patients underwent only radiotherapy $(27.6 \%)$. More than half of the respondents were male $(68.4 \%, \mathrm{n}=52)$, whereas $24(31.6 \%)$ were female. The assessment of the participants' performance status yielded results indicating an average level of all domains. Men performed better in terms of physical condition compared to a group of women $(p=0.010)$. Women experienced fatigue more frequently than men $(\mathrm{p}=0.012)$. Patients who had received radiation therapy combined with chemotherapy achieved on average better results in functional well-being (FWB) than the patients who had undergone radiotherapy only $(\mathrm{p}=0.046)$. Depression had a significant impact on all spheres of functioning $(\mathrm{p}<0.001)$ except social/family well-being.

Conclusion: The results pointed to the essential elements that should be taken into consideration in relation to treatment planning and providing care. Particular attention should be paid to women who suffered from depression and negative adaptation strategies that directly affect their functioning.

Keywords: functional status, FACIT-F, Mini-MAC, IADL, EORTC/RTOG, GDS, radiotherapy, chemotherapy

\section{Introduction}

Population aging is one of the challenges developed countries are facing today. According to the Central Statistical Office, the number of people aged over 60 in Poland will be an estimated 10.8 million in 2030, and 13.7 million in 2050. People
Department of Geriatrics, Collegium

Medicum, ul. Marii Curie-Sklodowskiej 9,

Bydgoszcz 85-094, Poland

Tel +48525854900

Fax +48525854921

Email muszalik@cm.umk.pl 
over that age will account for approximately $40 \%$ of the national population in 2050. In the following years, a seventy percent increase in neoplastic diseases affecting people over 60 is to be expected in Poland. The increase in morbidity will also occur worldwide. ${ }^{1}$ Due to such a major challenge, a new sub-discipline of medicine - geriatric oncology - was created. It utilizes an interdisciplinary and multidimensional approach to elderly patients with oncological problems. ${ }^{2}$

Cancer is deemed a serious life experience and a threat to a patient's health and normal functioning. Oncological treatment of elderly people is associated with the risk of deterioration of their general condition and performance status, which consequently leads to reduced autonomy. Not only is the aging period characterized by different physiologies closely related to involutional changes in the body but also by the burden of comorbidities and socio-economic hardship. ${ }^{2,3}$

Elderly patients constitute a heterogeneous population in terms of performance status. These are individuals who belong to a group characterized by good general condition, an intermediate group or a group with limited functional reserves. Some clinical and functional disorders are reversible, and silencing them can improve the patient's general condition and, therefore, increase the likelihood of a successful oncological treatment. Overall health, functional status, nutritional status, intellectual performance, previous treatment, and socio-economic status are of major importance. A dedicated Comprehensive Geriatric Assessment, later referred to as CGA, is used in planning oncological therapy. ${ }^{3,4}$

Comprehensive Geriatric Assessment (CGA) is a compilation of tools that can predict morbidity and mortality in elderly people. It has also been shown that various components of CGA influence clinical decision-making and predicting treatment outcomes in elderly cancer patients. ${ }^{5}$

The CGA helps to detect health problems and identify patients who are at a higher risk of mortality, functional decline, surgical and chemotherapy-related complications. The advantage of the CGA is that it identifies health problems that are not typically diagnosed during a routine examination of elderly cancer patients. ${ }^{6}$

It is extremely difficult to adapt to a neoplastic disease, which is manifested in behavioral, cognitive and emotional processes. Moreover, the adaptation strategy is an integral part of the patient's quality of life. ${ }^{7}$

Mental adaptation to the illness is equated with coping with stress during a traumatizing experience. Then, the patient focuses on overcoming the stressor. Antonovsky considers cancer one of the most critical events in one's life. Adaptation thus helps a person soothe emotional discomfort and restore a state of mental balance when faced with a new challenge. Therefore, adaptation serves the purpose of coping with disease, treatment and life changes. The theory of adaptation to a neoplastic disease is based on Lazarus' and Folkman's concept. According to it, the stress experienced as a consequence of cancer is the result of both physical decline and cognitive condition of an affected person. ${ }^{7,8}$ Adapting to a neoplastic disease requires coping with the disease itself as well as its immediate consequences, such as pain, bad mood, fatigue, changes in the quality of life and many others. Certain attitudes and strategies related to psychosocial adjustment determine the level of patients' functioning. ${ }^{7}$ There are two styles of fighting cancer referred to as constructive and destructive. The former is associated with a fighting spirit and positive re-evaluation strategies. Patients who are characterized by the fighting spirit strategy regard the disease as a personal challenge and decide to take action. Positive re-evaluation of the problem helps find hope and appreciate one's life so far. The latter is characterized by fear and helplessness-hopelessness strategy. The patient suffers from anxiety over the disease which is perceived as a threat. Helplessness-hopelessness strategy indicates a passive approach to the disease, as well as a feeling of impotence and confusion. ${ }^{8,9}$

Few scientific reports indicate the importance of assessing cancer patients' functioning and their quality of life. $^{10-12}$

The aim of the study was to assess the performance status, quality of life, and adaptation to the disease of elderly patients who underwent radiotherapy or chemotherapy combined with radiotherapy.

\section{Patients and Methods}

The study was conducted among the oncology ward patients at the Hospital of Ludwik Rydygier in Krakow. Seventy-six patients over 60 years of age diagnosed with cancer, undergoing radiotherapy or radiotherapy combined with chemotherapy, were qualified for the study. Age, inpatient status, diagnosis and histopathological confirmation of the tumor, qualification for treatment with radiotherapy or radiotherapy combined with chemotherapy, consent to participate were the criteria for the inclusion in the study. The exclusion criteria consisted of severe cognitive and mental disorders, treatment with palliative 
radiotherapy, and lack of consent to taking part in the study. The participants were informed about the purpose of the study. A research consent was obtained from the Bioethics Committee of the Jagiellonian University. This cross-sectional prospective study was conducted between February 2016 and May 2018 in accordance with the Declaration of Helsinki.

The age of the participants ranged from 60 to 86 years, and the mean $/ \pm$ SD were $69.3 \pm 6.8$ years, respectively. Regarding the age distribution, 43 (56.5\%) patients were between 60 and 69 years of age, 25 participants were between 70 and 79 years of age (32.8\%), and 8 participants were over $80(10.5 \%)$. The study group was diverse in terms of gender. More than half of the respondents were male $(68.4 \%, \mathrm{n}=52)$, whereas more than $1 / 3$ of the study participants $(31.6 \% \mathrm{n}=24)$ were female.

Functional status, health-related quality of life (HRQoL), and fatigue level were assessed at the end of the third week of treatment (radiotherapy or radiotherapy combined with chemotherapy) using the FACIT-F questionnaire (Version 4), which involved 5 areas of a chronically ill patient's life:

1. Physical well-being (PWB) - 7 questions

2. Social/family well-being (SWB) -7 questions

3. Emotional well-being (EWB) -6 questions

4. Functional well-being (FWB) -7 questions

5. Fatigue subscale (FS) - 13 questions

The evaluation scale of FACIT-F included the following five evaluating points: (i) Not at all: 0 points; (ii) a little bit: 1 point; (iii) somewhat: 2 points; (iv) quite a bit: 3 points; (v) very much: 4 points. Every patient was assessed in all the subscales after which the global scores were calculated. Higher scores signified better HRQoL and functional capacity. The following calculation methods were used: FACIT-F $=($ PWB score $)+($ SWB score $)$ $+($ EWB score $)+($ FWB score $)+($ FS score $) .{ }^{13}$

Scale of the post radiation reaction based on the Toxicity Criteria of the Radiation Therapy Oncology Group (RTOG) and the European Organization for Research and Treatment of Cancer (EORTC). EORTC/ RTOG consist: 0 - lack of reaction, 1 - erythema, 2 rash epitheliolysis, 3 - diffuse epitheliolysis, 4 - ulcers (bleeding and necrosis). ${ }^{14}$

MAC scale in the Polish adaptation by Juczyński, contained 29 items rated on a 4-point scale (1-4). This scale examines four strategies of coping with the disease: fighting spirit, anxiety, helplessness-hopelessness, and positive reevaluation. Each strategy consisted of 7 statements and the results were calculated separately for each strategy. The score for each strategy ranged from 7 to 28 points. Factor analysis identified two basic styles of coping with the disease: passive/destructive and constructive, which described a person who tried to cope with a difficult situation and adapt better to the disease. ${ }^{15}$

Lawton Instrumental Activities of Daily Living (IADL) measures daily complex activities such as using the phone, walking, shopping, preparing a meal, doing housework, DIY, preparing and taking medications, or managing money. The maximum number of points that could be obtained was $27 .{ }^{16}$

Yesavage Geriatric Depression Scale (15-point version) evaluates the severity of depression symptoms. The range from 11 to 15 points signified severe depression; 6 to 10 points - moderate depression; 0 to 5 points - lack of depression. ${ }^{17}$

ECOG scale (Eastern Cooperative Oncology Group Fitness Scale), also known as the Zubrod scale measures the overall performance status of the patient. It is popular in oncology, geriatrics, psychiatry and the evaluation of chronically ill patients. Its scale consisted of 6 levels, where 0 meant standard performance, in other words, the ability to carry out normal activities without restrictions; 1 - presence of symptoms of the disease, namely the ability to walk and do some light work; 2 - ability to perform personal activities, inability to work, which included less than half a day spent in bed; 3 - limited ability to perform personal activities, meaning a need to spend more than half a day in bed; 4 - need to spend the whole day in bed, and to be constantly cared for due to illness; 5 - death. ${ }^{18}$

In addition, an analysis of medical records, patient observation, and socio-demographic data was collected.

\section{Statistical Analysis}

The statistical analysis was performed using IBM SPSS V22.00. The collected data were subjected to quantitative, percentage and statistical analyses with the use of testing data distributions for normality using the Shapiro-Wilk test.

The r-Pearson correlation coefficient was used when all scales were calculated on a quantitative scale and the distributions of the variables were close to normal distribution. Pearson's correlation coefficient was thus used to determine the level of linear dependence between the variables. The degree of correlation of two variables had 
a value in the range between -1 and 1 . A value equal to 0 meant there was no linear relationship between the variables. A value closer to 1 or -1 indicated a strong relationship. In the case of a non-normal distribution or ordinal nature of the variables, the Spearman correlation coefficient was needed to examine the correlation between two sets of data with both of them expressed on an ordinal scale. This was achieved by assigning ranks to individual observations (numbers from 1 to $\mathrm{n}$ ), which made it possible to order them in a sequence (ascending or descending). In order to show the differences between the means of two different groups, the Student's $t$-test was used for normally distributed data. Fisher Snedecor's analysis of variance for two or more groups was performed, examining observations that depended on one or more factors simultaneously. It helped explain the probability of the selected factors which could have been the cause of the differences between the observed group means. Also, $\mathrm{P}<0.05$ was assumed as statistically significant. The obtained data were statistically analyzed using the program IBM SPSS V22.0.

\section{Results}

Most of the patients $37(48.6 \%)$ were treated with a combination of radiotherapy and chemotherapy, other patients were treated with radiotherapy or chemotherapy only. The characteristics of the study group according to the diagnosis and treatment method are presented in Table 1.

The functional assessment generally presents an average level in all dimensions of life. The results are presented in Table 2.

The Zubrod/ECOG Performance Status scale.

Among the respondents, only $4(5.26 \%)$ patients were able to perform their daily activities without any limitations, 44 participants $(57.89 \%)$ showed independence in terms of moving and doing light work. In 27 people $(35.53 \%)$ the ability to perform personal activities, the inability to work, and the need to spend less than half a day in bed were found. Only one patient (1.32\%) was fully dependent on other people.

Daily functioning assessment was performed using the Lawton scale (IADL). Test subjects obtained an average result of $18.03 / \mathrm{SD} \pm 4.21$.

The depression occurrence was assessed using GDS. Among the examined patients, 21 (27.63\%) were not depressed. However, the majority - 45 people (59.21\%) - experienced moderate depression, while 10 patients $(13.16 \%)$ suffered from escalating depression.

The EORTC/RTOG scale was used to assess the severity of the radiation reaction. In the study group, 45 people $(59.21 \%)$ did not have any skin lesions, 32 patients (30.26\%) had erythema, and 7 (9.21\%) had rash epitheliolysis. Only 1 person had diffuse epitheliolysis.

Table I Characteristic of Study Groups According to Diagnosis and Kind of Treatment $(N=76)$

\begin{tabular}{|c|c|c|c|c|c|}
\hline Diagnosis/Kind of Treatment & $\begin{array}{l}\text { Radiotherapy } \\
\text { n(\%) }\end{array}$ & $\begin{array}{l}\text { Chemotherapy } \\
\mathrm{n}(\%)\end{array}$ & $\begin{array}{l}\text { Radiotherapy + } \\
\text { Chemotherapy } \\
\text { n(\%) }\end{array}$ & $\begin{array}{l}\text { Radiotherapy + } \\
\text { Patients After } \\
\text { Surgery n(\%) }\end{array}$ & $\begin{array}{l}\text { Radiotherapy + } \\
\text { Chemotherapy + } \\
\text { Patients After Surgery } \\
\text { n(\%) }\end{array}$ \\
\hline Cancer of the oral cavity & $6(7.9)$ & $\mathrm{I}(\mathrm{I} .3)$ & $6(7.9)$ & - & - \\
\hline Head and neck cancer & $4(5.3)$ & - & $6(7.9)$ & - & $2(2.6)$ \\
\hline Cancer of esophagus & $2(2.6)$ & $\mathrm{I}(\mathrm{I} .3)$ & $4(5.3)$ & $\mathrm{I}(\mathrm{I} .3)$ & $3(3.9)$ \\
\hline $\begin{array}{l}\text { Cancer of cervical and } \\
\text { reproductive organs }\end{array}$ & $2(2.6)$ & $\mathrm{I}(\mathrm{I} .3)$ & $6(7.9)$ & - & - \\
\hline $\begin{array}{l}\text { Tumors of the central nervous } \\
\text { system (CNS) }\end{array}$ & $2(2.6)$ & - & $2(2.6)$ & $\mathrm{I}(\mathrm{I} .3)$ & $2(2.6)$ \\
\hline Cancer of the large intestine & $\mathrm{I}(\mathrm{I} .3)$ & - & $3(3.9)$ & - & $2(2.6)$ \\
\hline Lung cancer & $2(2.6)$ & - & $3(3.9)$ & $\mathrm{I}(\mathrm{I} .3)$ & - \\
\hline Cancer of the urinary bladder & $\mathrm{I}(\mathrm{I} .3)$ & - & $4(5.2)$ & - & $\mathrm{I}(\mathrm{I} .3)$ \\
\hline Gastric cancer & - & $\mathrm{I}(\mathrm{I} .3)$ & $2(2.6)$ & - & - \\
\hline Prostate cancer & - & - & - & $\mathrm{I}(\mathrm{I} .3)$ & - \\
\hline Cancer of the skin & $\mathrm{I}(\mathrm{I} .3)$ & - & - & - & - \\
\hline Focus primaries ignotus (FPI) & - & - & $\mathrm{I}(\mathrm{I} .3)$ & - & - \\
\hline Total & $21(27.6)$ & $4(5.3)$ & $37(48.6)$ & $4(5.3)$ & $10(13.2)$ \\
\hline
\end{tabular}


Table 2 Functional Assessment and HRQoL in the Study Group According to FACIT-F (N=76)

\begin{tabular}{|l|l|l|l|l|l|l|l|}
\hline Item & $\begin{array}{l}\text { Physical Well- } \\
\text { Being (PWB) }\end{array}$ & $\begin{array}{l}\text { Social/Family } \\
\text { Well-Being (SWB) }\end{array}$ & $\begin{array}{l}\text { Emotional Well- } \\
\text { Being (EWB) }\end{array}$ & $\begin{array}{l}\text { Functional Well- } \\
\text { Being (FWB) }\end{array}$ & $\begin{array}{l}\text { Fatigue } \\
\text { Subscale (FS) }\end{array}$ & $\begin{array}{l}\text { FACIT- } \\
\text { F TOI }\end{array}$ & $\begin{array}{l}\text { FACIT-F } \\
\text { Total Score }\end{array}$ \\
\hline & $0-28$ & $0-28$ & $0-24$ & $0-28$ & $0-52$ & $0-108$ & $0-160$ \\
Mean & 18.26 & 18.45 & 13.76 & 16.88 & 32.55 & 67.7 & 99.91 \\
SD & 5.97 & 5.39 & 5.21 & 5.24 & 10.5 & 19.1 & 22.65 \\
Min. & 3.0 & 0.0 & 2.0 & 5.0 & 5.0 & 15 & 46.0 \\
Max. & 28.0 & 24.0 & 24.0 & 28.0 & 51.0 & 102 & 146.0 \\
\hline
\end{tabular}

The most frequently chosen strategy of mental adaptation to cancer according to Mini-MAC was positive reevaluation and fighting spirit, while the least used one was the helplessness-hopelessness approach. Anxiety as a coping strategy obtained an average result. The average score for the destructive style was lower than for the constructive one. The results are presented in Table 3.

The gender of the respondents had an impact on their functioning and quality of life in terms of physical condition (PWB), fatigue (FS) and their overall assessment using FACIT-F TOI and FACIT-F. Males achieved higher scores for physical condition compared to the group of women $(p=0.010)$. Fatigue was more common in females than males $(p=0.012)$. Similarly, men obtained higher scores than women $(p=0.007)$ in the FACIT-F TOI scale, as well as in the FACIT-F scale $(\mathrm{p}=0.045)$, which confirms that men tend to enjoy a better performance status.

The results are presented in Table 4.

In the study population, no correlation was found between the patients' age and their functional assessment (FACIT-F) ( $\mathrm{p}>0.05)$.

The analysis showed that there was a positive correlation between the Lawton scale results (IADL) and the FACIT-F functional assessment. The results are presented in Table 5.

A statistically significant relationship was found between the occurrence of depression and the

Table 3 Results of Mini-MAC in the Study Group ( $N=76)$

\begin{tabular}{|l|l|l|l|l|l|}
\hline Mini-MAC & n & Min. & Max. & Mean & SD \\
\hline Anxiety & 76 & 7 & 26 & 17.09 & 3.77 \\
Fighting spirit & 76 & 14 & 28 & 21.3 & 3.19 \\
Helplessness- hopelessness & 76 & 12 & 24 & 17.26 & 2.01 \\
Positive reevaluation & 76 & 15 & 27 & 21.55 & 3.03 \\
Destructive style & 76 & $4^{*}$ & $9^{*}$ & 7.09 & 1.16 \\
Constructive style & 76 & $1^{*}$ & $8^{*}$ & 4.39 & 1.23 \\
\hline
\end{tabular}

Note: *Sten.

Abbreviations: $n$, number; Min - Max, minimum - maximum; M, mean; SD, standard deviation.
Table 4 Functional Assessment and HRQoL According to Gender ( $\mathrm{N}=76)$

\begin{tabular}{|l|l|l|l|l|l|l|l|}
\hline FACIT-F & Sex & $\mathbf{n}$ & Mean & SD & $\mathbf{t}$ & $\mathbf{d f}$ & $\mathbf{p}$ \\
\hline PWB & $\begin{array}{l}\text { Male } \\
\text { Female }\end{array}$ & $\begin{array}{l}52 \\
24\end{array}$ & $\begin{array}{l}19.44 \\
15.71\end{array}$ & $\begin{array}{l}5.66 \\
5.94\end{array}$ & 2.629 & 74 & 0.010 \\
\hline SWB & $\begin{array}{l}\text { Male } \\
\text { Female }\end{array}$ & $\begin{array}{l}52 \\
24\end{array}$ & $\begin{array}{l}18 \\
19.42\end{array}$ & $\begin{array}{l}5.01 \\
6.13\end{array}$ & -1.066 & 74 & 0.290 \\
\hline EWB & $\begin{array}{l}\text { Male } \\
\text { Female }\end{array}$ & $\begin{array}{l}52 \\
24\end{array}$ & $\begin{array}{l}13.79 \\
13.71\end{array}$ & $\begin{array}{l}5.43 \\
4.82\end{array}$ & 0.062 & 74 & 0.951 \\
\hline FWB & $\begin{array}{l}\text { Male } \\
\text { Female }\end{array}$ & 24 & $\begin{array}{l}17.6 \\
15.33\end{array}$ & $\begin{array}{l}5.37 \\
4.68\end{array}$ & 1.773 & 74 & 0.080 \\
\hline FS & $\begin{array}{l}\text { Male } \\
\text { Female }\end{array}$ & $\begin{array}{l}52 \\
24\end{array}$ & $\begin{array}{l}34.6 \\
28.13\end{array}$ & $\begin{array}{l}10.1 \\
9.99\end{array}$ & 2.589 & 74 & 0.012 \\
\hline FACIT-F TOI & $\begin{array}{l}\text { Male } \\
\text { Female }\end{array}$ & 52 & $\begin{array}{l}71.63 \\
59.17\end{array}$ & $\begin{array}{l}18.8 \\
17.32\end{array}$ & 2.753 & 74 & 0.007 \\
\hline FACIT-F & $\begin{array}{l}\text { Male } \\
\text { Female }\end{array}$ & $\begin{array}{l}52 \\
24\end{array}$ & $\begin{array}{l}103.42 \\
92.29\end{array}$ & $\begin{array}{l}22.01 \\
22.47\end{array}$ & 2.036 & 74 & 0.045 \\
\hline
\end{tabular}

Abbreviations: $n$, number; $M$, mean; SD, standard deviation; $d f$, degree of freedom, $t$, Student's $t$-test; PWB, physical well-being; SWB, social/family well-being; EWB, emotional well-being; FWB, functional well-being; FS, fatigue subscale.

performance status or quality of life of elderly people suffering from cancer $(p<0.05)$. Depression had a significant impact on all functioning spheres, except for social well-being (SWB). The results are presented in Table 6.

Table 5 Correlation Between FACIT-F and Lawton Scale (IADL)

\begin{tabular}{|l|l|l|}
\hline \multirow{2}{*}{ FACIT-F } & \multicolumn{2}{l|}{ IADL } \\
\cline { 2 - 3 } & $\mathbf{r}$ & $\mathbf{P}$ \\
\hline Physical well-being (PWB) & 0.37 I & 0.001 \\
Social/family well-being (SWB) & 0.157 & 0.175 \\
Emotional well-being (EWB) & 0.204 & 0.077 \\
Functional Well-being (FWB) & 0.5 & $\mathrm{P}<0.00$ I \\
Fatigue subscale (FS) & 0.529 & $\mathrm{P}<0.00$ I \\
FACIT-F TOI & 0.544 & $\mathrm{P}<0.00$ I \\
FACIT-F & 0.545 & $\mathrm{P}<0.00 \mathrm{I}$ \\
\hline
\end{tabular}

Abbreviation: r, Pearson's correlation coefficient. 
Table 6 Functional Assessment and Depression in the Study Group (N=76)

\begin{tabular}{|c|c|c|c|c|c|c|c|}
\hline FACIT-F & GDS & $\mathbf{n}$ & Mean & SD & Min & Max & Anova \\
\hline Physical well-being (PWB) & $\begin{array}{l}\text { Without depression } \\
\text { Depression moderate } \\
\text { Severe depression }\end{array}$ & $\begin{array}{l}21 \\
45 \\
10\end{array}$ & $\begin{array}{l}22.62 \\
17.33 \\
13.3\end{array}$ & $\begin{array}{l}4.38 \\
5.28 \\
6.51\end{array}$ & $\begin{array}{l}15 \\
5 \\
3\end{array}$ & $\begin{array}{l}28 \\
28 \\
21\end{array}$ & $\begin{array}{l}F=12.496 \\
d f=2 \\
P<0.001\end{array}$ \\
\hline Social/family well-being (SWB) & $\begin{array}{l}\text { Without depression } \\
\text { Depression moderate } \\
\text { Severe depression }\end{array}$ & $\begin{array}{l}21 \\
45 \\
10\end{array}$ & $\begin{array}{l}18.62 \\
19.13 \\
15\end{array}$ & $\begin{array}{l}3.80 \\
5.10 \\
8.17\end{array}$ & $\begin{array}{l}9 \\
0 \\
0\end{array}$ & $\begin{array}{l}24 \\
24 \\
24\end{array}$ & $\begin{array}{l}F=2.519 \\
d f=2 \\
P=0.088\end{array}$ \\
\hline Emotional well-being (EWB) & $\begin{array}{l}\text { Without depression } \\
\text { Depression moderate } \\
\text { Severe depression }\end{array}$ & $\begin{array}{l}21 \\
45 \\
10\end{array}$ & $\begin{array}{l}17.95 \\
12.24 \\
11.8\end{array}$ & $\begin{array}{l}3.59 \\
4.96 \\
4.54\end{array}$ & $\begin{array}{l}12 \\
2 \\
5\end{array}$ & $\begin{array}{l}24 \\
23 \\
20\end{array}$ & $\begin{array}{l}F=12.197 \\
d f=2 \\
P<0.001\end{array}$ \\
\hline Functional well-being (FWB) & $\begin{array}{l}\text { Without depression } \\
\text { Depression moderate } \\
\text { Severe depression }\end{array}$ & $\begin{array}{l}21 \\
45 \\
10\end{array}$ & $\begin{array}{l}20.67 \\
16.04 \\
12.7\end{array}$ & $\begin{array}{l}4.11 \\
4.79 \\
4.78\end{array}$ & $\begin{array}{l}13 \\
5 \\
7\end{array}$ & $\begin{array}{l}28 \\
25 \\
20\end{array}$ & $\begin{array}{l}F=I I .894 \\
d f=2 \\
P<0.001\end{array}$ \\
\hline Fatigue subscale (FS) & $\begin{array}{l}\text { Without depression } \\
\text { Depression moderate } \\
\text { Severe depression }\end{array}$ & $\begin{array}{l}21 \\
45 \\
10\end{array}$ & $\begin{array}{l}40.76 \\
30.67 \\
23.8\end{array}$ & $\begin{array}{l}9.04 \\
8.83 \\
9.80\end{array}$ & $\begin{array}{l}15 \\
13 \\
5\end{array}$ & $\begin{array}{l}51 \\
47 \\
35\end{array}$ & $\begin{array}{l}F=14.394 \\
d f=2 \\
P<0.001\end{array}$ \\
\hline FACIT-F TOI & $\begin{array}{l}\text { Without depression } \\
\text { Depression moderate } \\
\text { Severe depression }\end{array}$ & $\begin{array}{l}21 \\
45 \\
10\end{array}$ & $\begin{array}{l}84.05 \\
64.04 \\
49.8\end{array}$ & $\begin{array}{l}15.26 \\
15.55 \\
17.50\end{array}$ & $\begin{array}{l}46 \\
23 \\
15\end{array}$ & $\begin{array}{l}102 \\
94 \\
71\end{array}$ & $\begin{array}{l}F=19.029 \\
d f=2 \\
P<0.001\end{array}$ \\
\hline FACIT-F & $\begin{array}{l}\text { Without depression } \\
\text { Depression moderate } \\
\text { Severe depression }\end{array}$ & $\begin{array}{l}21 \\
45 \\
10\end{array}$ & $\begin{array}{l}120.62 \\
95.42 \\
76.6\end{array}$ & $\begin{array}{l}17.11 \\
17.86 \\
18.59\end{array}$ & $\begin{array}{l}79 \\
48 \\
46\end{array}$ & $\begin{array}{l}146 \\
132 \\
110\end{array}$ & $\begin{array}{l}F=24.334 \\
d f=2 \\
P<0.001\end{array}$ \\
\hline
\end{tabular}

Abbreviations: $n$, number; SD, standard deviation; df, degree of freedom; F, Fisher Snedecor test.

There is a relationship between the functional assessment of the elderly patients and their mental adaptation to cancer. Most noticeable is the negative correlation between anxiety and PWB, EWB, FWB, FS, FACIT-F TOI and FACIT-F $(\mathrm{p}<0.001)$.

A correlation between the fighting spirit and EWB $(\mathrm{p}=0.017)$ and FACIT-F $(\mathrm{p}=0.03)$ was also noted. Greater fighting spirit resulted in a more positive assessment of one's emotional state and functional well-being.

A negative correlation was obtained between the helplessness-hopelessness strategy and the scores in PWB $(p<0.001), \quad$ EWB $\quad(p=0.016), \quad$ FWB $\quad(p=0.001), \quad$ FS $(\mathrm{p}=0.035)$, FACIT-F TOI, FACIT-G and FACIT-F $(p<0.001)$. Therefore, greater tendency to psychological adaptation to cancer through helplessness-hopelessness results had a negative impact on the functioning of patients. A positive correlation was noted between positive re-evaluation and family/social well-being (SWB) $(p=0.033)$. The constructive style and SWB $(p=0.014)$ and EWB $(\mathrm{p}=0.042)$ proved to also have a positive correlation. These patients had a higher level of family/social well-being and enjoyed a better emotional state.
The analysis showed a statistically significant negative correlation between the destructive style and all factors: PWB, EWB, FWB, FS, FACIT-F TOI and FACIT-F $(p<0.001)$, A destructive mental attitude had a holistic negative impact on patients' functioning. The results are presented in Table 7.

Patients who received radiation therapy combined with chemotherapy achieved on average a higher score in functional well-being (FWB) than the patients undergoing only radiotherapy $(\mathrm{p}=0.046)$. There were no statistically significant differences for the remaining FACIT-F scores $(\mathrm{p}>0.05)$. The results are presented in Table 8 .

\section{Discussion}

Aging is an inevitable process resulting from a natural circle of life. An analysis of the process should be conducted according to biological, psychological and social dimensions. Aging is inevitably associated with functional performance deterioration, but it is worth pointing out that elderly people should be assessed individually, as aging is an individual process, which should be considered in the context of genetic determinants, adaptation skills and life experiences. 
Table 7 Correlation Between Functional Assessment and Mental Adaptation to Oncological Disease in the Study Group (N=76)

\begin{tabular}{|c|c|c|c|c|c|c|c|c|c|c|c|c|}
\hline \multirow[t]{3}{*}{ FACIT-F } & \multicolumn{8}{|c|}{ Mini-MAC } & \multirow{2}{*}{\multicolumn{2}{|c|}{$\begin{array}{l}\text { Constructive } \\
\text { Style }\end{array}$}} & \multirow{2}{*}{\multicolumn{2}{|c|}{$\begin{array}{l}\text { Destructive } \\
\text { Style }\end{array}$}} \\
\hline & \multicolumn{2}{|c|}{$\begin{array}{l}\text { Anxiety } \\
\text { Attitude }\end{array}$} & \multicolumn{2}{|c|}{$\begin{array}{l}\text { Fighting } \\
\text { Spirit }\end{array}$} & \multicolumn{2}{|c|}{$\begin{array}{l}\text { Helplessness- } \\
\text { Hopelessness }\end{array}$} & \multicolumn{2}{|c|}{$\begin{array}{l}\text { Positive Re- } \\
\text { Evaluation }\end{array}$} & & & & \\
\hline & $r$ & $p$ & $r$ & $p$ & $\mathbf{r}$ & $p$ & $\mathbf{r}$ & $p$ & $\mathbf{r}$ & $p$ & $\mathbf{r}$ & $\mathbf{p}$ \\
\hline PWB & -0.474 & 0.000 & 0.103 & 0.378 & -0.404 & 0.000 & -0.213 & 0.065 & $-0,047$ & 0.684 & -0.486 & $\mathrm{p}<0.001$ \\
\hline SWB & 0.096 & 0.408 & 0.175 & 0.131 & 0,026 & 0.825 & 0.246 & 0.033 & 0,281 & 0.014 & 0.043 & 0.711 \\
\hline EWB & -0.611 & $p<0.001$ & 0.274 & 0.017 & -0.276 & 0.016 & 0.099 & 0.397 & 0,233 & 0.042 & -0.551 & $p<0.001$ \\
\hline FWB & -0.472 & $p<0.001$ & 0.177 & 0.126 & -0.378 & 0.001 & 0.022 & 0.852 & 0,113 & 0.332 & -0.504 & $p<0.001$ \\
\hline FS & -0.476 & $\mathrm{P}<0.001$ & 0.165 & 0.156 & -0.242 & 0.035 & -0.054 & 0.643 & 0,075 & 0.519 & -0.469 & $p<0.001$ \\
\hline FACIT-F TOI & -0.539 & $p<0.001$ & 0.171 & 0.14 & -0.362 & 0.001 & -0.09 & 0.438 & 0,057 & 0.623 & -0.547 & $p<0.001$ \\
\hline FACIT-F & -0.574 & $\mathrm{p}<0.001$ & 0.249 & 0.03 & -0.364 & 0.001 & 0.005 & 0.967 & 0,169 & 0.144 & -0.58 & $\mathrm{p}<0.001$ \\
\hline
\end{tabular}

Abbreviations: $p$, statistical significance coefficient; $r$, Spearman correlation coefficient; PWB, physical well-being; SWB, social/family well-being; EWB, emotional well-being; FWB, functional well-being; FS, fatigue subscale.

Table 8 Correlation Between Functional Assessment and Methods of Treatment in the Study Group (N=76)

\begin{tabular}{|c|c|c|c|c|c|c|c|}
\hline FACIT-F & Methods of Treatments & $\mathbf{n}$ & $\mathbf{M}$ & SD & $\mathbf{t}$ & df & $\mathbf{p}$ \\
\hline Physical well-being (PWB) & $\begin{array}{l}\text { Radiotherapy } \\
\text { Radiotherapy combined with chemotherapy }\end{array}$ & $\begin{array}{l}30 \\
46\end{array}$ & $\begin{array}{l}16.83 \\
19.2\end{array}$ & $\begin{array}{l}6.597 \\
5.41\end{array}$ & -1.705 & 74 & 0.092 \\
\hline Social/family well-being (SWB) & $\begin{array}{l}\text { Radiotherapy } \\
\text { Radiotherapy combined with chemotherapy }\end{array}$ & $\begin{array}{l}30 \\
46\end{array}$ & $\begin{array}{l}17.93 \\
18.78\end{array}$ & $\begin{array}{l}5.285 \\
5.489\end{array}$ & -0.669 & 74 & 0.506 \\
\hline Emotional well-being (EWB) & $\begin{array}{l}\text { Radiotherapy } \\
\text { Radiotherapy combined with chemotherapy }\end{array}$ & $\begin{array}{l}30 \\
46\end{array}$ & $\begin{array}{l}12.93 \\
14.3\end{array}$ & $\begin{array}{l}5.099 \\
5.274\end{array}$ & -1.122 & 74 & 0.265 \\
\hline Functional well-being (FWB) & $\begin{array}{l}\text { Radiotherapy } \\
\text { Radiotherapy combined with chemotherapy }\end{array}$ & $\begin{array}{l}30 \\
46\end{array}$ & $\begin{array}{l}15.4 \\
17.85\end{array}$ & $\begin{array}{l}5.599 \\
4.821\end{array}$ & -2.029 & 74 & 0.046 \\
\hline Fatigue subscale (FS) & $\begin{array}{l}\text { Radiotherapy } \\
\text { Radiotherapy combined with chemotherapy }\end{array}$ & $\begin{array}{l}30 \\
46\end{array}$ & $\begin{array}{l}30.53 \\
33.87\end{array}$ & $\begin{array}{l}12,42 \\
8.948\end{array}$ & -1.361 & 74 & 0.178 \\
\hline FACIT-F TOI & $\begin{array}{l}\text { Radiotherapy } \\
\text { Radiotherapy combined with chemotherapy }\end{array}$ & $\begin{array}{l}30 \\
46\end{array}$ & $\begin{array}{l}62.77 \\
70.91\end{array}$ & $\begin{array}{l}21.733 \\
16.72\end{array}$ & -1.842 & 74 & 0.069 \\
\hline FACIT-F & $\begin{array}{l}\text { Radiotherapy } \\
\text { Radiotherapy combined with chemotherapy }\end{array}$ & $\begin{array}{l}30 \\
46\end{array}$ & $\begin{array}{l}93.63 \\
104\end{array}$ & $\begin{array}{l}24.948 \\
20.201\end{array}$ & -1.991 & 74 & 0.05 \\
\hline
\end{tabular}

Abbreviations: $n$, number; $M$, mean; SD, standard deviation; $p$, statistical significance coefficient; df, degree of freedom; $t$, Student's $t$-test.

The objective of the study was to assess the performance status, quality of life and adaptation to the disease of patients treated with a combination of radiotherapy and chemotherapy or with radiotherapy only. The study involved 76 patients with oncological diseases, which are presented in Table 1. In this study, the patients' general functioning scores were at an average level in all the particular FACIT-F subscales.

The importance of carrying out an analysis of patientreported symptoms and toxicities resulting from the treatment should be emphasized. The research conducted by Baratelli et al found that the introduction of PRO (PatientReported Outcomes) into clinical practice, thanks to the active role of nurses, was possible and resulted in a high level of patient satisfaction and a significant improvement in the quality of life compared to the traditional medical consultation. ${ }^{10}$ Based on their research, the authors also recommend regular assessment of the cancer patients' quality of life as part of standard treatment. ${ }^{11}$

What is more, the impact of selected sociodemographic factors on the functioning of patients undergoing oncological treatment was analyzed. On the one hand, there was no correlation between the age of the participants and the FACIT-F assessment of functional performance. On the other hand, the study found a relationship between gender and physical condition (PWB) $(p=0.010)$ and fatigue (FS) ( $p$ 
$=0.012$ ). Participants' gender had an impact on the FACITTOI $(p=0.007)$ and FACIT-F $(p=0.045)$ scores as well. Thus, it was confirmed that men enjoyed a better physical condition and functional performance, while suffering from less fatigue compared to women. Moreover, men chose the strategy of positive reevaluation and a constructive style more often than women did. There was no correlation between the age of the respondents and their mental adaptation to cancer.

In a study by Kołpa et al, carried out on a group of 100 oncological patients, no correlation was found between adaptation to cancer and the gender of the respondents. ${ }^{8}$ The results obtained in a study by Lelonek et al, carried out on a group of 110 surgical ward patients, coincided with the results in this paper and indicated that males were better at adapting to the disease. ${ }^{19}$ The studies by Muszalik et al, carried out among women with breast cancer undergoing radiotherapy using the FACIT-F scale, showed a relationship between age, education and marital status and the level of functional performance. Women with breast cancer who underwent radiotherapy achieved an average quality of life. ${ }^{20}$ Other studies by Solvik et al and Montan et al, also using the FACIT-F scale, confirmed the relationship between gender and fatigue. Women showed a higher level of fatigue compared to men. ${ }^{13,21}$

Also, the scores obtained in the Lawton scale (IADL), as well as the results of the FACIT-F functional assessment, were analyzed. The research showed that patients with better performance in terms of instrumental activities assessed more positively their physical condition and functioning in everyday life, while presenting a lower level of fatigue and a satisfactory general functional performance. No such reports have been found in the current literature.

In addition, the examination of the relationship between the occurrence of a radiation reaction and the functional performance of elderly patients showed that people who did not develop skin reactions after radiotherapy enjoyed the greatest performance status. On the other hand, people with erythema assessed their fitness as much worse. Similarly, no data suggestive of such a relationship have been found in the current literature.

This research assessed the impact of depression on the functional status of elderly cancer patients. Studies have shown that patients with no signs of depression obtained higher functional performance scores, whereas people with severe depression suffered from the lowest level of functional performance. Similar results were presented in studies by Zboin et al carried out among chronically ill patients living in nursing homes; it was shown that a deteriorated emotional state and symptoms of depression had a negative effect on functional performance. ${ }^{22}$

The impact of the oncological treatment method on the functional state and mental adaptation to cancer was analyzed. It has been shown that the method of oncological treatment affects the functional well-being (FWB). The use of radiotherapy combined with chemotherapy in the studied population improved their functioning in everyday life more than the use of radiotherapy alone $(p=0.046)$.

Also, the research by Religioni et al among lung cancer patients who received chemotherapy in the last year, found that they obtained higher scores in strategies of positive adaptation to cancer. ${ }^{23}$

However, Kołpa et al presented different results, stating that the applied oncological treatment did not have any impact on the adaptation strategy. ${ }^{8}$ Despite extensive research, no unequivocal reports on the impact of the applied oncological treatment on the functional status of elderly patients have been found in the literature.

Nevertheless, this research shows that there is a relationship between the functional performance of the elderly and their mental adaptation to neoplastic disease. People presenting a constructive style of adaptation to cancer were characterized by a higher family/social well-being and a better emotional state. Patients characterized by the destructive style suffered from a worse physical and emotional state and did not function as well in everyday life. They also suffered from greater fatigue, while their functional performance was at a lower level. Similar results were obtained in the study by Kulpa et al who examined 100 patients from the Oncology Center in Warsaw. It has been shown that constructive strategies translated into a much better functioning of the patient in all dimensions. Such patients presented better overall health compared to patients who manifested a destructive strategy. ${ }^{7}$

\section{Conclusions}

To sum up, the functional performance of patients according to the FACIT-F scale for all dimensions was found to be on an average level. Depression of moderate intensity was found in more than half of the respondents and it had a significant impact on all spheres of their functioning, except for social/family well-being. The most frequently chosen disease adaptation strategy was positive re-evaluation and fighting spirit. There was a negative correlation between helplessnesshopelessness strategy, destructive style, anxiety, and all domains of functioning. The sex of the respondents had 
an impact on the assessment's results in the domains of physical condition, fatigue and general functioning. Men achieved higher scores than women in these domains. There was a relationship between the method of oncological treatment and functional status in everyday life: patients who underwent radiotherapy combined with chemotherapy performed significantly better than those who underwent only radiotherapy.

\section{Acknowledgments}

We would like to thank all the participants of the study and the nurses who were willing to support us while the research.

\section{Author Contributions}

All authors made substantial contributions to conception and design, acquisition of data, or analysis and interpretation of data; took part in drafting the article or revising it critically for important intellectual content; agreed to submit to the current journal; gave final approval of the version to be published; and agree to be accountable for all aspects of the work.

\section{Disclosure}

The authors report no conflicts of interest in this work.

\section{References}

1. Kamińska - Gawryluk E. Sytuacja osób starszych w Polsce w 2018 roku.[The situation of elderly people in Poland in 2018]. Warszawa: Główny Urząd Statystyczny[Central Statistical Office] GUS; 2020

2. Ocalewski J, Izdebski P. Doświadczanie choroby nowotworowej wśród osób w późnej dorosłości. Przegląd badań.[Experiencing cancer among people in late adulthood. Research review]. Pol Gerontol. 2016;24:251-258.

3. Łacko A. Specyfika leczenia chorych na nowotwory w podeszłym wieku.[The specificity of treatment of elderly cancer patients]. Med Wieku Podeszlego.[Med.aging]. 2012;1:7-11.

4. Krzemieniecki K, Kowalski D, Meder J. Zalecenia postępowania diagnostyczno-terapeutycznego w nowotworach złośliwych. [Recommendations for diagnostic and therapeutic procedures in malignant neoplasms]. Gdańsk: Via Medica; 2013.

5. Mohile SG, Magnuson A. Comprehensive geriatric assessment in oncology. Interdiscip Top Gerontol. 2013;38:85-103.

6. Torres $\mathrm{CH}$, Hsu T. Comprehensive geriatric assessment in the older adult with cancer: a review. Eur Urol Focus. 2017;3(4-5):330-339.

7. Kulpa M, Owczarek K, Stypuła-Ciuba B. Przystosowanie psychiczne do choroby nowotworowej a jakość życia uwarunkowana stanem zdrowia u chorych onkologicznych.[Mental adaptation to neoplastic disease and the quality of life conditioned by health in oncological patients]. Paliat Med. 2013;5(3):106-113.
8. Kołpa M, Wywrot-Kozłowska JB, Grochowska A. Czynniki determinujące akceptację i przystosowanie do choroby nowotworowej[Factors determining the acceptance and adaptation to neoplastic disease]. Pieleg Chir Angiol [Surg Angiol Nurs]. 2015;3:165-169.

9. Smoleń E, Słysz M, Jarema M, Hombek K, Kalita K. Factors determining the style of adaptation on the disease in patients treated oncologically. J Educ Health Sport. 2017;7(8):1715-1732.

10. Baratelli C, Turco CGC, Lacidogna G, et al. The role of patientreported outcomes in outpatients receiving active anti-cancer treatment: impact on patients' quality of life. Support Care Cancer. 2019;27(12):4697-4704

11. Yucel B, Akkaş EA, Eren OY, et al. The impact of radiotherapy on quality of life for cancer patients: a longitudinal study. Support Care Cancer. 2014;22(9):2479-2487.

12. Reeve BB, Mitchell SA, Dueck AC, et al. Recommended patient-reported core set of symptoms to measure in adult cancer treatment trials. J Natl Cancer Inst. 2014;106(7):dju129. doi:10.1093/jnci/dju129

13. Montan I, Lowe B, Cella D, Mehnert A, Hinz A. General population norms for the Functional Assessment of Chronic Illness Therapy (FACIT) - fatigue scale. Value Health. 2018;21:1313-1321.

14. Michalewski J. Odczyny popromienne w radioterapii oraz popromienne zapalenie skóry.[Radiation reactions in radiotherapy and radiation dermatitis]. Lett Onco Sci. 2017;14(4):104-109.

15. Juczyński Z. Narzędzia Pomiaru w Promocji I Psychologii Zdrowia. [Measurement Tools in Health Promotion and Psychology]. PTP, Warszawa: Wydawnictwo Pracownia Testów Psychologicznych. [Psychological Test Laboratory Publishing House]; 2012.

16. Lawton MP, Brody EM. Assessment of older people: self - maintaining and instrumental activities of daily living. Gerontologist. 1969;9(3):179-186.

17. Yesavage JA, Brink T, Lom O, Huang V, Adey M, Leirer VO. Development and validation of a geriatric depression screening scale: a preliminary report. J Psychiatr Res. 1983;17(1):37-49.

18. Oken MM, Creech RH, Tormey DC, et al. Toxicity and response criteria of the Eastern cooperative oncology group. Am J Clin Oncol. 1982;5(6):649-655.

19. Lelonek B, Kaczmarczyk M. Przystosowanie do choroby u pacjentów leczonych na oddziale chirurgicznym.[Adaptation to the disease in patients treated in the surgical ward]. Studia Medyczne [Medical Studies]. 2011;24:45-52.

20. Muszalik M, Kołucka-Pluta M, Kędziora-Kornatowska K, Robaczewska J. Quality of life of women with breast cancer undergoing radiotherapy using the functional assessment of chronic illness therapy-fatigue questionnaire. Clin Interv Aging. 2016;11:1489-1494.

21. Solvik E, Ytrehus S, Utne I, Grov EK. Pain, fatigue, anxiety and depression in older home - dwelling people with cancer. Nurs Open. 2019;7(1):430-438.

22. Zboin B, Bińczyk K, Korzonek M, Biskup M. Wpływ sprawności funkcjonalnej na częstość występowania depresji wśród pensjonariuszy placówek pomocy społecznej.[The impact of functional ability on the incidence of depression among residents of social welfare institutions]. Zdrowie I Dobrostan.[Health and Well-Being]. 2014;1:127-145.

23. Religioni U, Czerwl A, Deptała A. Przystosowanie psychiczne pacjentów do wybranych chorób nowotworowych.[Mental adaptation of patients to selected neoplastic diseases]. Psychiatr Pol. 2015. 


\section{Publish your work in this journal}

Clinical Interventions in Aging is an international, peer-reviewed journal focusing on evidence-based reports on the value or lack thereof of treatments intended to prevent or delay the onset of maladaptive correlates of aging in human beings. This journal is indexed on PubMed Central, MedLine, CAS, Scopus and the Elsevier
Bibliographic databases. The manuscript management system is completely online and includes a very quick and fair peer-review system, which is all easy to use. Visit http://www.dovepress.com/ testimonials.php to read real quotes from published authors. 